\title{
Isolation and characterization of marine sponge-associated Streptomyces sp. NMF6 strain producing secondary metabolite(s) possessing antimicrobial, antioxidant, anticancer, and antiviral activities
}

\author{
Nayer Mohamed Fahmy ${ }^{1 *}$ (1) and Asmaa Mohamed Abdel-Tawab²
}

\begin{abstract}
Background: Actinomycetes associated with marine sponge represent a promising source of bioactive compounds. Herein, we report the isolation, identification, and bioactivity evaluation of Streptomyces sp. NMF6 associated with the marine sponge Diacarnus ardoukobae.

Results: Results showed that the strain belonged to the genus Streptomyces, and it was designated as Streptomyces sp. NMF6 with the GenBank accession number MW015111. Ethyl acetate (EtOAc) extract of the strain NMF6 demonstrated a promising antimicrobial activity against Staphylococcus aureus, Enterococcus faecalis, Vibrio damsela, and Candida albicans and a strong antioxidant activity, which were confirmed by DPPH, ferric-reducing power, and phosphomolybdenum assays; results are expressed as ascorbic acid equivalents. NMF6 extract also demonstrated cytotoxicity against breast cancer cell line (MCF-7), hepatocellular carcinoma cell line (Hep-G2), and human colon carcinoma cell line (HCT-116); the selectivity index values were $<2$. The extract showed promising antiviral activity against HSV-1, CoxB4, and hepatitis A viruses at concentrations that were nontoxic to the host cells, with the selectivity index values being $13.25,9.42$, and 8.25 , respectively. GC-MS analysis of the extract showed the presence of 20 compounds, with bis(2-ethylhexyl) phthalate being the major component (48\%).
\end{abstract}

Conclusions: Our study indicates that the marine sponge-associated Streptomyces sp. NMF6 strain is a potential source of bioactive compounds that could be developed into therapeutic agents.

Keywords: Streptomyces, Marine sponge, Antiviral, Anticancer, Antioxidant, Antimicrobial

\section{Background}

Exploration of novel drugs is crucial to overcome the failure of the currently used medications. It is known that pathogenic bacteria have developed resistance to new generations of antibiotics, and some of them may tolerate all the known antibiotics and cause acute infections that necessitate more toxic and more expensive

\footnotetext{
* Correspondence: nmfahmy6@yahoo.com

${ }^{1}$ Marine Microbiology Laboratory, National Institute of Oceanography and Fisheries, Cairo, Egypt

Full list of author information is available at the end of the article
}

drugs [1]. Like bacteria, viruses mutate over time and develop resistance toward antiviral agents [2]. Cancer is still one of the most life-threatening diseases worldwide. An estimated 10 million cancer-related deaths among 18 million cases diagnosed with cancer were reported in 2018, which is expected to increase to 26.4 million annual cases worldwide, with 17 million deaths by the year 2030 [3, 4]. Oxidative stress is associated with the development of several pathologies such as cancer, Alzheimer's disease, cardiovascular disease, early aging, ischemia, liver injury, arteriosclerosis, inflammation, skin

\section{Springer Open}

(- The Author(s). 2021 Open Access This article is licensed under a Creative Commons Attribution 4.0 International License, which permits use, sharing, adaptation, distribution and reproduction in any medium or format, as long as you give appropriate credit to the original author(s) and the source, provide a link to the Creative Commons licence, and indicate if changes were made. The images or other third party material in this article are included in the article's Creative Commons licence, unless indicated otherwise in a credit line to the material. If material is not included in the article's Creative Commons licence and your intended use is not permitted by statutory regulation or exceeds the permitted use, you will need to obtain permission directly from the copyright holder. To view a copy of this licence, visit http://creativecommons.org/licenses/by/4.0/. 
damages, diabetes mellitus, and arthritis. The most currently used synthetic antioxidants such as tert-butylated hydroquinone (TBHQ), butylated hydro anisole (BHA), and butylated hydro toluene (BHT) are unsafe and could exert carcinogenic and toxic side effects $[5,6]$. Hence, the search for bioactive compounds could lead to the discovery of novel compounds that could solve all these chemotherapy issues.

Natural products obtained from different sources (including microorganisms, animals, and plants) have provided important medicines for the treatment of diverse human and animal diseases and represent a potential source of more potent drugs to overcome the failure of conventional drugs $[7,8]$. Microorganisms are more amenable for the large-scale production of bioactive compounds and would overcome the limitations of obtaining drugs by field-harvesting of large quantities of macroorganisms [9]. Till date, marine microorganisms could be considered as a relatively undervalued source for the discovery of bioactive compounds and could provide novel bioactive compounds in terms of structure and bioactivity $[10,11]$. Among marine microbes, actinomycetes are excellent producers of bioactive compounds possessing different biological activities such as antitumor, antibiotic, immunosuppressive, antioxidant, antiviral, and enzyme inhibition properties [12].

The majority of actinomycetes recovered from marine sources have originated from marine sponges, with Streptomyces being the most abundant genus. Approximately $22 \%$ of all the bioactive compounds obtained from marine actinomycetes have been derived from sponge-associated species [13, 14]. Several studies have reported the isolation of various novel bioactive compounds from sponge-associated streptomycetes [15-20]. Therefore, we hypothesized that the marine sponge Diacarnus ardoukobae could host bioactive actinomycetes. In this study, we report the isolation, characterization, and bioactivity screening of Streptomyces sp. NMF6 isolated from $D$. ardoukobae collected from the mangrove ecosystem located $17 \mathrm{~km}$ south of Safaga at the Egyptian Red Sea coast. We evaluated the antimicrobial, antioxidant, anticancer, and antiviral activities of the ethyl acetate extract (EtOAc) prepared from Streptomyces sp. NMF6. We also determined the chemical constituents of the extract using GC-MS analysis.

\section{Methods}

\section{Sample collection and isolation of actinomycetes}

D. ardoukobae was collected in May 2019 from the mangrove ecosystem located $17 \mathrm{~km}$ south of Safaga $\left(26^{\circ} 36^{\prime}\right.$ $53^{\prime \prime} \mathrm{N}$ and $\left.34^{\circ} 24^{\prime} 47.71^{\prime \prime} \mathrm{E}\right)$ and transferred to the laboratory in sterile plastic bags containing sea water within $3 \mathrm{~h}$ of collection. The sponge tissue was homogenized in sterile sea water using WiseTis Homogenizer
HG 15D (witeg Labortechnik GmbH, Germany). The homogenate was plated on starch casein nitrate agar (SCNA) prepared using 50\% sea water and supplemented with cycloheximide $(50 \mathrm{mg} / \mathrm{L})$ and nalidixic acid $(25 \mathrm{mg} / \mathrm{L})$ and incubated for 14 days at $30^{\circ} \mathrm{C}$. Actinomycetes colonies were purified by streaking on SCNA medium and maintained on slant cultures at $4{ }^{\circ} \mathrm{C}$ [21].

\section{Screening of actinomycetes for antimicrobial activity}

The isolates were grown in Waksman's broth-containing (g/L): glucose, 10; peptone, 5; beef extract, 5-for 14 days under shaking conditions $(180 \mathrm{rpm})$ at $30{ }^{\circ} \mathrm{C}$ and tested for antimicrobial activity by the agar well diffusion method [22] against Enterococcus faecalis ATCC 29212, Staphylococcus aureus ATTC 25923, Escherichia coli ATCC 8739, Pseudomonas aeruginosa ATCC 4027, Vibrio damsela, Candida albicans ATCC 10231, Fusarium sp., Rhizoctonia solani, and Aspergillus niger. Thereafter, an isolate designated as NMF6 was selected for further characterization and bioactivity evaluation as it exhibited a broad-spectrum antimicrobial activity and produced a brown extracellular metabolite when cultured in Waksman's broth.

\section{Phenotypic characterization of strain NMF6}

The morphological, biochemical, and physiological characteristics of the strain NMF6 were extensively investigated. The strain was grown on different media and under different culture conditions, including different $\mathrm{NaCl}$ concentrations $(1-10 \%, w / v)$, different $\mathrm{pH}$ values (1-10), and different temperatures $\left(10-50{ }^{\circ} \mathrm{C}\right)$, after which the color of aerial and substrate mycelia, production of diffusible pigment, and utilization of carbon sources were analyzed as described by Shrilling and Gottlieb [23]. The morphology of spore chain and the spore surface texture were observed by scanning electron microscopy [24]. Gelatin liquefaction, nitrate reduction, and extracellular hydrolytic enzyme production (amylase, cellulase, protease, and lipase) were evaluated as described by Williams et al. [25]. The behavior of the strain toward 10 antibiotics was evaluated using the disk diffusion method [26].

\section{Molecular identification}

Genomic DNA was isolated as described by Sambrook and Russell [27]. Polymerase chain reaction (PCR) was conducted to amplify the 16S rDNA gene of the strain NMF6 using universal primers p27F (5'-AGAGTTTG ATCCTGGCTCAG-3') and 1492R (5'-TACGGCTACC TTGTTACGACTT-3'). The PCR product was purified and sequenced, and the BLAST program (www.ncbi. nlm.nih.gov/blst) was used to evaluate the similarity. Multiple sequence alignment and phylogenetic tree 
construction were performed using the Mega-X software, version 10.1.7 [17, 28].

\section{Fermentation and extraction of secondary metabolites}

The crude extract of the strain NMF6 was obtained by fermentation and extraction. Briefly, the starting inoculum was prepared by growing the strain in tryptone soya broth for 5 days under shaking conditions $(180 \mathrm{rpm})$ at $30{ }^{\circ} \mathrm{C}$. Then, $2 \%$ of the starting inoculum was used to inoculate Waksman's broth prepared using 50\% seawater, distributed into 1-L Erlenmeyer flasks (400 mL/flask), and incubated in a rotary shaker incubator $(180 \mathrm{rpm})$ at $30{ }^{\circ} \mathrm{C}$ for 14 days. Cell-free supernatants were collected after centrifugation at $8000 \mathrm{rpm}$ and extracted using equal volumes of ethyl acetate, and the organic phase was collected and evaporated using a rotary evaporator [29, 30]. Stock solutions of the crude extract in methanol and dimethyl sulfoxide (DMSO) were prepared separately and stored at $4{ }^{\circ} \mathrm{C}$ until used in different assays. The crude extract was screened for different biological activities, including antimicrobial, antioxidant, anticancer, and antiviral effects.

\section{Determination of antimicrobial activity}

The antimicrobial potential of EtOAc was evaluated by the disk diffusion method. Briefly, sterile filter paper disks (6-mm diameter) were impregnated with $30 \mu \mathrm{L}$ (containing $0.5 \mathrm{mg}$ ) of methanol stock solution of the crude extract; control disks were impregnated with $30 \mu \mathrm{L}$ of methanol without the extract. The disks were maintained at room temperature until the complete evaporation of methanol and then placed on the surface of agar plates previously seeded, separately, with the test microorganisms. The plates were incubated under suitable conditions for each of the test microorganisms, and the diameter of the inhibition zone was measured. The minimum inhibitory concentration (MIC) was determined using the broth dilution method. Briefly, twofold serial dilutions (62.5$975 \mu \mathrm{g} / \mathrm{mL}$ ) of NMF6 extract were prepared in Muller Hinton broth. Negative control which should be turbid was prepared with the solvent (DMSO) without the extract, and the uninoculated media was considered as positive control. All of the tubes were inoculated with bacterial suspensions $(0.5$ McFarland turbidity standards), incubated at $37{ }^{\circ} \mathrm{C}$ for $24 \mathrm{~h}$. The growth was measured at $625 \mathrm{~nm}$ using the JENWAY 6800 spectrophotometer [31].

\section{Determination of antioxidant activity}

Three different assays were used to evaluate the antioxidant potential of the crude extract of the strain NMF6. In all assays, all the experiments were conducted in triplicate with a sample dose of 25-150 $\mu \mathrm{g}$, and a parallel experiment was conducted using ascorbic acid $(2-15 \mu \mathrm{g})$ as positive control, after which an ascorbic acid standard curve was developed. The antioxidant capacities of the extract were calculated as vitamin $C$ equivalent antioxidant capacity values.

\section{DPPH assay}

The DPPH (1-diphenyl-2-picrylhydrazyl) radicalscavenging activity of NMF6 extract was evaluated as described by Kasangana et al. [32]. Equal volumes of the extract $(25,50,75,100,125$, and $150 \mu \mathrm{g} / \mathrm{mL})$ or vitamin $C(2-10 \mu \mathrm{g} / \mathrm{mL})$ were mixed with a methanolic solution of DPPH $(0.2 \mathrm{mM})$ and incubated in the dark. After $30 \mathrm{~min}$, the absorbance values of all samples and the blank (containing pure methanol instead of sample) were measured at $517 \mathrm{~nm}$ using the JENWAY 6800 spectrophotometer. The absorbance response $(\mathrm{y})$ of vitamin $\mathrm{C}\left(\mathrm{y}=7.4948 \mathrm{x}-3.4408, \mathrm{R}^{2}=\right.$ $0.9976)$ and concentrations $(0-10 \mu \mathrm{g} / \mathrm{mL})$ was linear, and the results are expressed as ascorbic acid equivalent antioxidant capacity (AAEAC) values. All experiments were conducted in triplicate, and the DPPH scavenging activity and ascorbic acid equivalents were calculated using the following equations:

$$
\begin{aligned}
& \% \mathrm{DPPH} \text { scavenging activity }=\frac{\text { Abs Blank-Abs sample }}{\text { Abs Blank }} \times 100 \\
& \text { Ascorbic acid equivalents }(\mu \mathrm{g})=\frac{\text { Abs of sample }+3.4408}{7.4948}
\end{aligned}
$$

\section{Phosphomolybdenum assay}

The total antioxidant activity of NMF6 extract was evaluated using the phosphomolybdenum method. Briefly, $2.7 \mathrm{~mL}$ of phosphomolybdenum reagent $(28 \mathrm{mM}$ sodium phosphate, $0.6 \mathrm{M}$ sulfuric acid, and $4 \mathrm{mM}$ ammonium molybdate) was mixed with $0.3 \mathrm{~mL}$ of the extract or vitamin $C$ to obtain various final concentrations $(25,50,75$, 100,125 , and $150 \mu \mathrm{g} / \mathrm{mL}$ ) and $2-10 \mu \mathrm{g} / \mathrm{mL}$, respectively. The mixture was incubated at $95{ }^{\circ} \mathrm{C}$ for $90 \mathrm{~min}$, and the absorbance was measured at $695 \mathrm{~nm}$ using the JENWAY 6800 spectrophotometer [32]. The absorbance response (y) of vitamin $C\left(y=0.097 x-0.0041, R^{2}=0.9999\right)$ and concentrations $(0-10 \mu \mathrm{g} / \mathrm{mL})$ was linear. All experiments were conducted in triplicate, and the AAEAC values were calculated using the following equation:

$$
\text { Ascorbic acid equivalents }(\mu \mathrm{g})=\frac{\text { Abs of sample }+0.0041}{0.097}
$$

\section{Ferric-reducing power assay}

The ferric-reducing power of NMF6 extract was evaluated as described by Aliyu et al. [33]. Briefly, $0.5 \mathrm{~mL}$ containing different doses of the extracts $(25,50,75$, 
100,125 , and $150 \mu \mathrm{g}$ ) was mixed with $0.5 \mathrm{~mL}$ of phosphate buffer solution $(200 \mathrm{mM}, \mathrm{pH}=6.6)$ and $0.5 \mathrm{~mL}$ of $1 \%$ potassium ferricyanide $\left[\mathrm{K}_{3} \mathrm{Fe}(\mathrm{CN})_{6}\right]$. The mixture was incubated at $50{ }^{\circ} \mathrm{C}$ for $20 \mathrm{~min}$, allowed to cool to room temperature, and mixed with $0.5 \mathrm{~mL}$ of $10 \%$ trichloroacetic acid. A volume of $0.5 \mathrm{~mL}$ of this mixture was mixed with $0.5 \mathrm{~mL}$ of distilled water and $0.1 \mathrm{~mL}$ of $\mathrm{FeCl}_{3}(0.1 \%$ solution $)$ and allowed to stand for $10 \mathrm{~min}$, after which the absorbance was measured at $700 \mathrm{~nm}$ using the JENWAY 6800 spectrophotometer. The absorbance response $(y)$ of ascorbic acid $(y=0.0205 x-$ $\left.0.0055, \mathrm{R}^{2}=0.994\right)$ and concentrations $(0-10 \mu \mathrm{g} / \mathrm{mL})$ was linear, and the results were calculated as AAEAC values using the following equation:

Ascorbic acid equivalents $(\mu \mathrm{g})=\frac{\text { Abs of sample }+0.0055}{0.0205}$

\section{Determination of anticancer activity}

The cytotoxic effect of NMF6 extract on three human cancer cell lines, viz., breast cancer cell line (MCF-7), hepatocellular carcinoma cell line (Hep-G2), and human colon carcinoma cell line (HCT-116), and normal human lung fibroblast cells (Wi-38) was evaluated using 3-(4,5-dimethylthiazol-2-yl)-2,5-diphenyltetrazolium bromide (MTT) assay. Cells were cultured in Dulbecco's modified Eagle's medium supplemented with $10 \%$ fetal bovine serum and $1 \%$ antibiotic solution (penicillin-G and streptomycin) in 96-well plates and incubated for $24 \mathrm{~h}$ at $37{ }^{\circ} \mathrm{C}$ and $5 \% \mathrm{CO}_{2}$. The cells were washed twice and seeded in $0.1 \mathrm{~mL}$ of Roswell Park Memorial Institute (RPMI) 1640 medium containing different concentrations of the extract $(15.62-500 \mu \mathrm{g} / \mathrm{mL})$. A control experiment was conducted using only solvent (DMSO) without the sample. The plates were incubated at $37{ }^{\circ} \mathrm{C}$ for $72 \mathrm{~h}$ with $5 \% \mathrm{CO}_{2}$ and then treated with $20 \mu \mathrm{L}$ of MTT solution $(5 \mathrm{mg} / \mathrm{mL}$ in PBS) and further incubated for $1-5$ $\mathrm{h}$. The medium was decanted, and the formazan, formed by metabolically active cells, was dissolved in $100 \mu \mathrm{L}$ of DMSO. Absorbance was measured at 570 $\mathrm{nm}$, and the background was subtracted at $620 \mathrm{~nm}$ [34-36]. The values of $\mathrm{IC}_{50}$ (concentration of compound required to inhibit cell viability by $50 \%$ ) were calculated from the dose-dependent curve using the GraphPad InStat software. The selectivity index (SI) was calculated as the ratio of $\mathrm{IC}_{50}$ for normal cells to that of cancer cells. Variations in cellular morphology of treated and nontreated cells were visualized using a phase-contrast inverted microscope (Olympus, Japan) equipped with a digital camera and the Cell Sense software.

\section{Determination of antiviral activity Cell line and viruses}

The Vero cell line (ATCC: CCL-81) and herpes simplex virus (HSV-1), Coxsackie B4 virus (CoxB4), and hepatitis A virus (HAV) were used in this study. All viruses were obtained from the Microbiology Department, Faculty of Medicine for Girls, Al-Azhar University, Cairo.

\section{Determination of cytotoxicity of NMF6 strain extract on Vero cells}

The cytotoxic activity of the different concentrations $(15.62,31.25,62.5,125,250$, and $500 \mu \mathrm{g} / \mathrm{mL})$ of NMF6 extract on viral host cells (Vero cells, ATCC CCL-81) was evaluated using MTT assay as described earlier. The maximum tolerated concentration, which did not cause toxicity or morphological alteration toward Vero cells, was determined, and the percentage of cytotoxicity was calculated as $[(\mathrm{A}-\mathrm{B}) / \mathrm{A} \times 100]$, where $\mathrm{A}$ and $\mathrm{B}$ are the absorbance values of control and treated cells, respectively. The $\mathrm{CC}_{50}$ value (the concentration that caused $50 \%$ toxicity) was determined from the cell viability standard curve using the GraphPad Prism 5 software program [37, 38].

\section{Antiviral assay}

Antiviral activity was evaluated using MTT assay as described previously [38]. Briefly, the Vero cell culture (10, 000 cells $/ 200 \mu \mathrm{L}$ of media) was dispensed into each well of a 96-well plate (three wells were left empty as blank control). The plate was incubated overnight at $37{ }^{\circ} \mathrm{C}$ under $5 \% \mathrm{CO}_{2}$ to permit adherence of cells to the wells. Next, $100 \mu \mathrm{L}$ of virus/sample suspension, prepared by mixing equal volumes of nonlethal concentrations (15.62, 7.8, and $3.9 \mu \mathrm{L} / \mathrm{mL}$ ) of NMF6 extract and virus suspension and incubated for $1 \mathrm{~h}$, was added to each well, shaken for $5 \mathrm{~min}$ at $150 \mathrm{rpm}$, and incubated at 37 ${ }^{\circ} \mathrm{C}$ for $24 \mathrm{~h}$ under $5 \% \mathrm{CO}_{2}$ to permit the activity of the virus. Then, $20 \mu \mathrm{L}$ of MTT solution $(5 \mathrm{mg} / \mathrm{mL}$ in phosphate-buffered saline) was added to each well, mixed thoroughly by shaking for $5 \mathrm{~min}$ at $150 \mathrm{rpm}$, and incubated for $1-5 \mathrm{~h}$ to allow metabolism of MTT. The medium was poured off, and the plate was dried to remove any residue. The MTT metabolic product (formazan) was resuspended in $200 \mu \mathrm{L}$ of DMSO and shaken well to ensure complete solubility. The optical density was determined at $560 \mathrm{~nm}$, and the background was subtracted at $620 \mathrm{~nm}$. The $\mathrm{IC}_{50}$ value (the concentration required to reduce the viral cytopathic effect to 50\%) was estimated using the GraphPad Prism 5 software program. The SI value was calculated as the ratio of $\mathrm{CC}_{50}$ to $\mathrm{IC}_{50}$, and the antiviral activity was calculated as follows: 
Antiviral activity $(\%)=(A-B) /(C-B) \times 100$

where $\mathrm{A}, \mathrm{B}$, and $\mathrm{C}$ are the absorbance values of sample, virus, and cell control, respectively.

\section{GC-MS analysis}

GC-MS analysis was conducted according to previously described methods [39]. Briefly, the Thermo Scientific Trace GC1310 gas chromatograph attached with a mass spectrometer was used to identify the individual components present in the EtOAc of strain NMF6. The instrument was coupled with the Agilent J\&W DB-5 column, and the temperature was set at $40-280{ }^{\circ} \mathrm{C}$. The sample was injected at $300{ }^{\circ} \mathrm{C}$ and eluted under low-pressure helium gas $(1 \mathrm{~mL} / \mathrm{min})$. The mass spectra of the compounds were compared with Wiley Registry8e library.

\section{Infrared spectra}

The FT-IR spectra of NMF6 extract were recorded using a Bruker Tensor 27 FTIR spectrophotometer and the conventional $\mathrm{KBr}$ disk method. A total of 32 scans were collected at a spectral resolution of $4 \mathrm{~cm}^{-1}$.

\section{Results}

Isolation of sponge-associated actinomycetes

Eight isolates of actinomycetes were retrieved from the marine sponge $D$. ardoukobae collected from the mangrove ecosystem. All isolates exhibited colonial morphology of the genus Streptomyces. The isolates were screened for antimicrobial activity. Due to distinct antimicrobial activity, one isolate, designated as strain NMF6, was selected for further characterization and bioactivity evaluation.

\section{Morphological and biochemical characterization of strain NMF6}

The strain NMF6 is gram-positive, aerobic, and filamentous with simple spiral spore chain and spiny spore surface. The strain grew well on all tested solid media with variable colony colors and produced a brown diffusible pigment on only Waksman's medium. It produced catalase and hydrolyzed carboxymethyl cellulose, starch, gelatin, and Tween 80 but failed to reduce nitrate or hydrolyze urea. Among the carbon sources tested, the strain utilized only glucose, starch, and glycerol as the sole carbon source. It tolerated up to $4 \%$ of sodium chloride and grew well at a temperature range of 20-45 ${ }^{\circ} \mathrm{C}$ and a pH range of 4-10. The strain was resistant to clindamycin $5 \mu \mathrm{g}$, flucloxacillin $5 \mu \mathrm{g}$, ciprofoxacillin 5 $\mu \mathrm{g}$, and trimethoprim/sulfamethoxazole 1.5/23.75 $\mu \mathrm{g}$ (Tables 1, 2 and Fig. 1).
Table 1 Morphological, biochemical, and physiological characteristics of NMF6 strain

\begin{tabular}{|c|c|}
\hline Characteristic & Result \\
\hline \multicolumn{2}{|l|}{ Morphological characteristics } \\
\hline Gram & + \\
\hline Spore chain & Spiral \\
\hline Spore surface & Spiny \\
\hline Diffusible pigment & + \\
\hline \multicolumn{2}{|l|}{ Physiological and biochemical properties } \\
\hline \multicolumn{2}{|l|}{ Production of } \\
\hline Cellulase & + \\
\hline Amylase & + \\
\hline Lipase & + \\
\hline Gelatinase & + \\
\hline Urease & - \\
\hline Catalase & + \\
\hline Nitrate reduction & - \\
\hline \multicolumn{2}{|l|}{ Utilization of carbon sources } \\
\hline Glucose & + \\
\hline Fructose & - \\
\hline Maltose & - \\
\hline Lactose & - \\
\hline Arabinose & - \\
\hline Xylose & - \\
\hline Starch & + \\
\hline Glycerol & + \\
\hline Sucrose & - \\
\hline Mannitol & - \\
\hline \multicolumn{2}{|l|}{ Resistance to } \\
\hline Amikacin $30 \mathrm{mcg}$ & - \\
\hline Flucloxacillin 5 mcg & + \\
\hline Clindamycin 2 mcg & + \\
\hline Erythrocin 15 mcg & - \\
\hline Amoxicillin/clavulanic acid 20/10 mcg & + \\
\hline Streptomycin $10 \mathrm{mcg}$ & - \\
\hline Ciprofoxacillin 5 mcg & + \\
\hline Tobramycin 10 mcg & - \\
\hline Trimethoprime/sulphamethoxazole $1.5 / 23.75 \mathrm{mcg}$ & - \\
\hline \multicolumn{2}{|l|}{ Growth at different $\mathrm{pH}$} \\
\hline $4-10$ & + \\
\hline \multicolumn{2}{|l|}{ Growth at different $\mathrm{NaCl}(w / v, \%)$} \\
\hline $0-4$ & + \\
\hline \multicolumn{2}{|l|}{ Growth at different temperature } \\
\hline $20-45^{\circ} \mathrm{C}$ & + \\
\hline $50^{\circ} \mathrm{C}$ & - \\
\hline
\end{tabular}


Table 2 Cultural characteristics of strain NMF6 on various media at $30{ }^{\circ} \mathrm{C}$ for 14 days

\begin{tabular}{|c|c|c|c|c|}
\hline \multirow[t]{2}{*}{ Media } & \multirow[t]{2}{*}{ Growth } & \multicolumn{2}{|l|}{ Colony color } & \multirow{2}{*}{$\begin{array}{l}\text { Diffusible } \\
\text { pigment }\end{array}$} \\
\hline & & Aerial mycelium & Substrate mycelium & \\
\hline ISP1 & Fastidious & Gray & Green & - \\
\hline ISP2 & Fastidious & Gray & Brown & - \\
\hline ISP4 & Fastidious & Gray & Green & - \\
\hline ISP5 & Fastidious & Gray & Yellow brown & - \\
\hline ISP7 & Fastidious & White & Yellow brown & - \\
\hline SCNA & Fastidious & White & Yellow brown & - \\
\hline WGA & Fastidious & Gray & Brown & Brown \\
\hline NA & Fastidious & Gray & Green & - \\
\hline
\end{tabular}

SCNA starch casein nitrate agar, WGA Waksman's glucose agar, NA Nutrient agar

\section{Molecular phylogeny of strain NMF6}

The partial 16S rDNA sequence of strain NMF6 was determined and compared with the sequences available in GenBank. The strain shared the highest similarity with $16 \mathrm{~S}$ rDNA sequences of Streptomyces sp. MS 3/20, S. chartreusis strain NBRC 12753, and S. althioticus strain JCM 4344 (99.68\%) and formed a single clade with these strains upon phylogenetic analysis based on the neighbor-joining method. The strain was deposited in GenBank as Streptomyces sp. NMF6 under the accession number MW015111 (Fig. 2).

\section{Antimicrobial activity of Streptomyces sp. NMF6}

The antimicrobial activity of the EtOAc of strain NMF6 was evaluated using the disk diffusion method, and the MIC values were determined using the broth dilution method. The extract exhibited antimicrobial activity against $S$. aureus, E. faecalis, $V$. damsela, and C. albicans but failed to inhibit any of the tested filamentous fungi. The extract demonstrated the maximum antimicrobial activity against $V$. damsela followed by E. faecalis and C. albicans. S. aureus was the most resistant test microorganism and had the highest MIC value (Table 3).

\section{Antioxidant activity}

The antioxidant capacity of Streptomyces sp. NMF6 extract in a dose range of $25-150 \mu \mathrm{g}$ was evaluated by different assays and expressed as ascorbic acid equivalents. The Streptomyces sp. NMF6 extract exhibited significant antioxidant activity over a dose range of 25-150 $\mu \mathrm{g}$. The antioxidant activity of the extract in all assays was dosedependent, and the ascorbic acid equivalent values were the highest in the DPPH assay followed by phosphomolybdenum and ferric-reducing power assays (Table 4).

\section{Anticancer activity}

Figure 3 depicts the cytotoxic effect of Streptomyces sp. NMF6 extract toward three human cancer cell lines, viz., breast cancer cell line (MCF-7), hepatocellular carcinoma cell line, (Hep-G2), and human colon carcinoma cell line (HCT-116), and normal human lung fibroblast cells (Wi-38). The NMF6 extract markedly reduced the viability of all the tested human cancer cell lines at concentrations ranging from 15.62 to $500 \mu \mathrm{g} / \mathrm{mL}$. The viabilities of the cancer cell lines at the maximum concentration of the extract $(500 \mu \mathrm{g} / \mathrm{mL})$ tested were $5 \%, 4.89 \%$, and $4.84 \%$ for HCT-116, Hep-G2, and MCF7 , respectively. The normal human lung fibroblast cells (Wi-38) were less sensitive than the cancer cell lines;

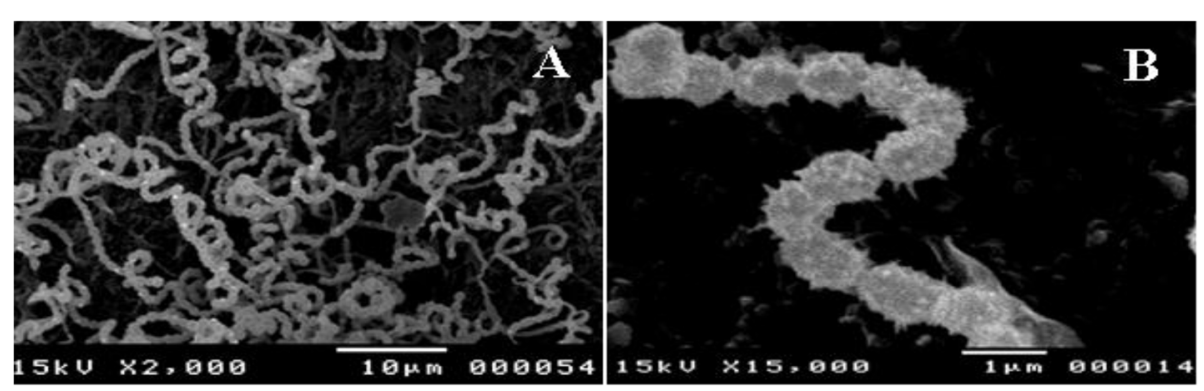

Fig. 1 Scanning electron micrograph of NMF6 strain showing spiral spore chain (A) and spiny spore surface (B) 


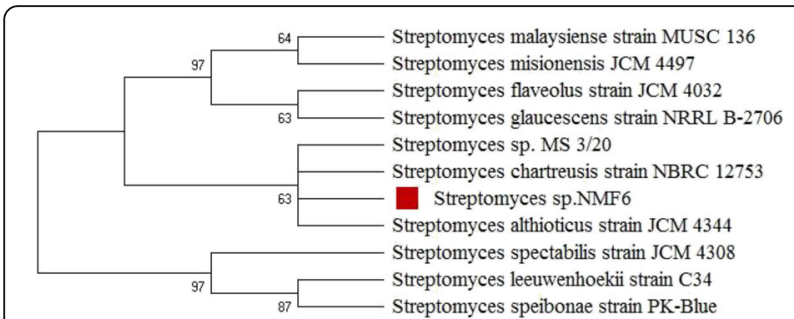

Fig. 2 Neighbor-joining phylogenetic tree based on 16S rRNA sequences of NMF6 strain and related Streptomyces species. Numbers at nodes are bootstrap values (> 50\%) based on 1000 resamplings

however; the SI values for the cancer cell lines were $<2$ (Table 5). In addition to cell viability assessment using MTT assay, the effect of strain NMF6 extract on the appearance of cells was investigated. Treatment of cancer cells (HCT-116, Hep-G2, MCF-7) with NMF6 strain extract visibly altered the cell morphology. At concentrations $\leq 31.25 \mu \mathrm{g} / \mathrm{mL}$, few apoptic bodies were observed while at concentrations $(62.5-500 \mu \mathrm{g} / \mathrm{mL})$ of the extract all cancer cells exhibited cytoplasm condensation, nuclear margination, and chromatin fragmentation. Normal human lung fibroblast cells (Wi-38) showed only cell shrinkage upon treatment with the extract (Fig. 4).

\section{Antiviral activity}

The maximum nontoxic concentration of NMF6 extract on Vero cells and the antiviral activity of concentrations equal to or below this concentration were evaluated using MTT assay. The 50\% cytotoxic concentration $\left(\mathrm{CC}_{50}\right)$ of the extract on Vero cells was $80.26 \mu \mathrm{g} / \mathrm{mL}$, and the maximum nontoxic concentration was $15.62 \mu \mathrm{g} /$ $\mathrm{mL}$ (Fig. 5). The antiviral activities of the extract at the maximum nontoxic concentration were $96.55 \%, 68.34 \%$, and $40 \%$ against HSV-1, CoxB4, and HAV, respectively (Fig. 6). At the lowest tested concentration $(3.9 \mu \mathrm{g} / \mathrm{mL})$ of the extract, the antiviral activity was extremely weak against HAV and CoxB4, with the values being 0.15\% and $1.68 \%$, respectively (Fig. 6). The SI values, which were 13.25 , 9.42, and 8.25 for HSV-1, CoxB4, and HAV, respectively, also confirmed these results (Table 6).

Table 3 Antimicrobial activity and MIC $(\mu \mathrm{g} / \mathrm{mL})$ of Streptomyces sp. NMF6

\begin{tabular}{lll}
\hline Test microorganism & *Zone of inhibition $(\mathbf{m m})$ & MIC $(\boldsymbol{\mu g} / \mathbf{m L})$ \\
\hline Staphylococcus aureus & $16 \pm 1$ & 520 \\
Candida albicans & $17 \pm 1$ & 490 \\
Vibrio damsela & $25.3 \pm 1.5$ & 335 \\
Enterococcus faecalis & $22.7 \pm 1.5$ & 365 \\
\hline
\end{tabular}

*Values are mean \pm SD $(n=3)$

\section{GC-MS analysis}

The chemical composition of the EtOAc of strain NMF6 was evaluated by GC-MS analysis. A total of 20 chemical compounds were identified by comparing their mass spectra with the Wiley Registry8e library based on their retention time, molecular formula, and molecular weight (Fig. 7). As shown in Table 6, >50\% of whole extract represents phthalate esters, diisobutyl phthalate (12) (1.43\%), phthalic acid, butyl 8-methylnonyl ester (16) (3.74\%), and bis(2-ethylhexyl) phthalate (20) (48.90\%), whereas polyketide compounds accounted for approximately $25 \%$ of whole extract and miscellaneous compounds.

\section{Fourier-transform infrared spectroscopy (FTIR)}

FTIR analysis of the EtOAc of strain NMF6 revealed the presence of signal at $1454 \mathrm{~cm}^{-1}$ that accounted for an aromatic benzene ring, which confirmed the presence of phthalate benzene ring. Moreover, the presence of signal at $1627 \mathrm{~cm}^{-1}$ confirmed the presence of carbonyl group $(\mathbf{C}=\mathbf{O})$ of both aldehyde and ketone, which confirmed the presence of fatty acid and polyketide derivatives. The presence of signals at $2853-2953 \mathrm{~cm}^{-1}$ was attributed to the presence of aliphatic $(\mathbf{C H})$ group, and finally, the presence of signal at $3267 \mathrm{~cm}^{-1}$ accounted for the $(\mathrm{OH})$ group (Fig. 8).

\section{Discussion}

We isolated a total of eight actinomycetes associated with the marine sponge $D$. ardoukobae and selected one isolate, coded as strain NMF6, on the basis of the broadspectrum antimicrobial activity, for further characterization and bioactivity evaluation. The strain was identified as a species belonging to the genus Streptomyces and designated as Streptomyces sp. NMF6 with the GenBank accession number MW015111. Our results showed that the strain NMF6 produces secondary metabolite(s) exhibiting different bioactivities such as antimicrobial, antioxidant, anticancer, and antiviral effects.

Marine sponges host diverse microbial communities, with biomass accounting for up to $25 \%$ of the sponge volume, that produce bioactive compounds formerly attributed to host sponge. Actinomycetes are among the most common phyla associated with marine sponges, with Streptomyces being the most abundant genus [13, 40]. Our results showed that $D$. ardoukobae hosts bioactive actinomycetes, with most of them belonging to the genus Streptomyces.

The reliable taxonomy of prokaryotes, especially the genus Streptomyces, requires data from both DNA-based methods and phenotypic characterization [41]. Several studies have demonstrated that the highly similar Streptomyces strain may differ in terms of biochemical profiles and carbon source utilization [42, 43]. Therefore, to 
Table 4 Antioxidant activities demonstrated by Streptomyces sp. NMF6 extract expressed as ascorbic acid equivalents

\begin{tabular}{llll}
\hline \begin{tabular}{l} 
Sample $\begin{array}{l}\text { mass } \\
(\boldsymbol{\mu g})\end{array}$ \\
\cline { 2 - 3 }
\end{tabular} & *Ascorbic acid equivalent $(\boldsymbol{\mu g})$ & Phosphomolybdenum assay & Ferric-reducing power assay \\
\hline 25 & $3.37 \pm 0.28$ & $2.36 \pm 0.19$ & $1.91 \pm 0.14$ \\
50 & $5.84 \pm 0.29$ & $4.10 \pm 0.04$ & $2.79 \pm 0.23$ \\
75 & $7.96 \pm 0.10$ & $5.28 \pm 0.30$ & $3.98 \pm 0.22$ \\
100 & $9.63 \pm 0.08$ & $6.22 \pm 0.02$ & $5.13 \pm 0.12$ \\
125 & $10.78 \pm 0.05$ & $7.32 \pm 0.07$ & $6.53 \pm 0.12$ \\
150 & $11.83 \pm 0.14$ & $7.70 \pm 0.03$ & $7.67 \pm 0.15$ \\
\hline
\end{tabular}

*Data are expressed as mean \pm standard deviation $(n=3)$

provide better understanding and complement the phylogenetic analysis of NMF6 strain, we conducted detailed biochemical and physiological characterization. Our data revealed that the strain NMF6 belonged to the genus Streptomyces and could grow at different ranges of $\mathrm{NaCl}(0-4 \%, \mathrm{w} / \mathrm{v}), \mathrm{pH}(4-10)$, and temperature $\left(20-45^{\circ} \mathrm{C}\right)$. These results indicate that the strain is well adapted to the environmental conditions of the mangrove environment, where there are continuous changes in salinity and temperature due to tidal inundation $[44,45]$.

Streptomyces species are well known for the production of secondary metabolites possessing different bioactivities such as antitumor, antiviral, antioxidant, antihypertensive, immunosuppressant, and especially antimicrobial properties, which play a role as defense compounds against microbes competing in the natural environment [46]. The strain NMF6 exhibited antimicrobial activity against members of gram-positive and gram-negative bacteria and yeast.

Free radicals such as reactive oxygen species and reactive nitrogen species are involved in several biological processes in the human body, such as apoptosis, immunity, and cell signaling. Endogenous antioxidative mechanisms, which could involve enzymatic compounds such

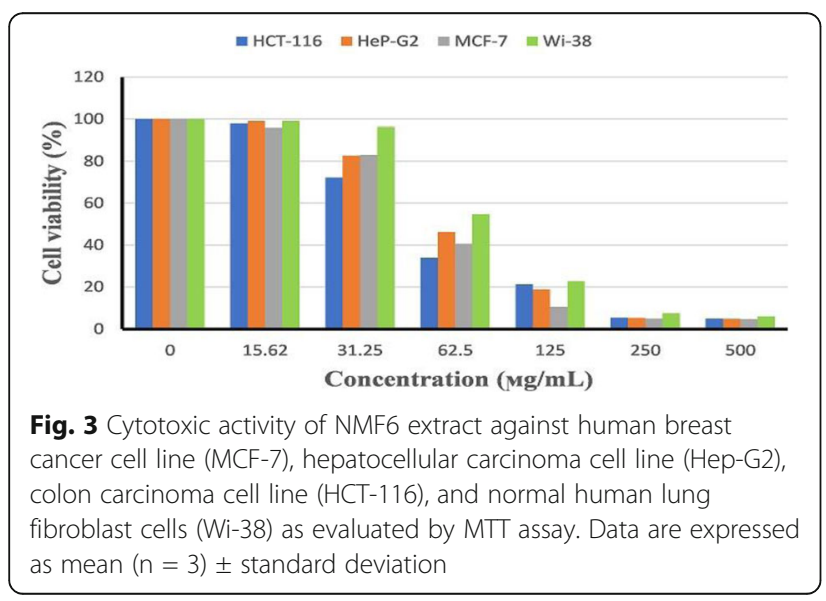

as superoxide dismutase, catalase (CAT), and glutathione peroxidase or nonenzymatic compounds such as albumin and bilirubin, control the levels of free radicals, as excessive free radicals could damage vital molecules (proteins, lipids, carbohydrates, and DNA) and generate several pathologies. However, under stress conditions, endogenous antioxidative mechanisms became compromised and the free radicals accumulate and result in oxidative stress [47]. The uptake of exogenous antioxidant compounds reduces oxidative stress and prevents several diseases such as cardiovascular disorders, rheumatoid arthritis, ulcerogenesis, acquired immunodeficiency disease, among others. Besides medicinal applications, antioxidants prevent oxidation processes in stored food, especially those containing unsaturated fatty acids [48]. Microorganisms, especially actinomycetes, are a promising source of natural antioxidants that are safer than the hazardous synthetic chemicals [6]. Several studies have reported the antioxidant potential of different Streptomyces species isolated from different marine habitats [4953]. The extract of Streptomyces sp. NMF6 demonstrated promising antioxidant activities when tested by the DPPH assay, which implies hydrogen atom transfer, and both phosphomolybdenum and ferric-reducing power assays, which imply single electron transfer (SET). These results indicate that the extract contains bioactive compound(s) exhibiting antioxidant activity through different mechanisms. To evaluate the antioxidant potential of natural extracts and obtain a better understanding of their activities, it is necessary to apply several assays indicating different mechanisms [51, 53], and the results should be expressed as equivalent of a standard antioxidant to allow comparison between the results of different studies and avoid misinterpretation due to variation in applying the methods by different research groups [54]. Therefore, in the present study, we evaluated the antioxidant capacity of Streptomyces sp. NMF6 extract using different assays and expressed the results as ascorbic acid equivalents. 
Table $\mathbf{5} \mathrm{IC}_{50}$ and selectivity index of Streptomyces sp. NMF6 extract

\begin{tabular}{|c|c|c|}
\hline \multirow{2}{*}{$\begin{array}{l}\text { Cell } \\
\text { line }\end{array}$} & \multirow[t]{2}{*}{$\mathrm{IC}_{50}$} & Selectivity index (SI) \\
\hline & & $\left(\mathrm{IC}_{50}\right.$ of Wi-38 normal cell line/IC $\mathrm{C}_{50}$ of cancer cell lines) \\
\hline MCF-7 & 55.65 & 1.5 \\
\hline Hep-G2 & 59.39 & 1.4 \\
\hline HCT-116 & 49.85 & 1.67 \\
\hline Wi-38 & 83.56 & \\
\hline
\end{tabular}

Cancer is one of the most fatal diseases worldwide. In 2018, the International Agency for Research on Cancer reported approximately 10 million deaths among 18 million cancer-diagnosed patients in 185 countries [3]. The search for novel anticancer compounds from natural sources is crucial to overcome the phenomenon of drug resistance and the harmful side effects associated with some verified synthetic anticancer drugs [55]. Therefore, researchers investigating natural products have conducted considerable work, especially on marine resources, to fulfill the urgent need for new anticancer drugs with novel modes of action and fewer side effects. Natural products obtained from marine microbes have been confirmed to possess promising anticancer activity in in vitro and in vivo models against various tumor cell lines with different mechanisms of action [56]. Among microorganisms, the genus Streptomyces has been used to produce several verified anticancer compounds such as bleomycin, dactinomycin, mitomycin, and doxorubicin $[57,58]$. Moreover, several studies have reported the

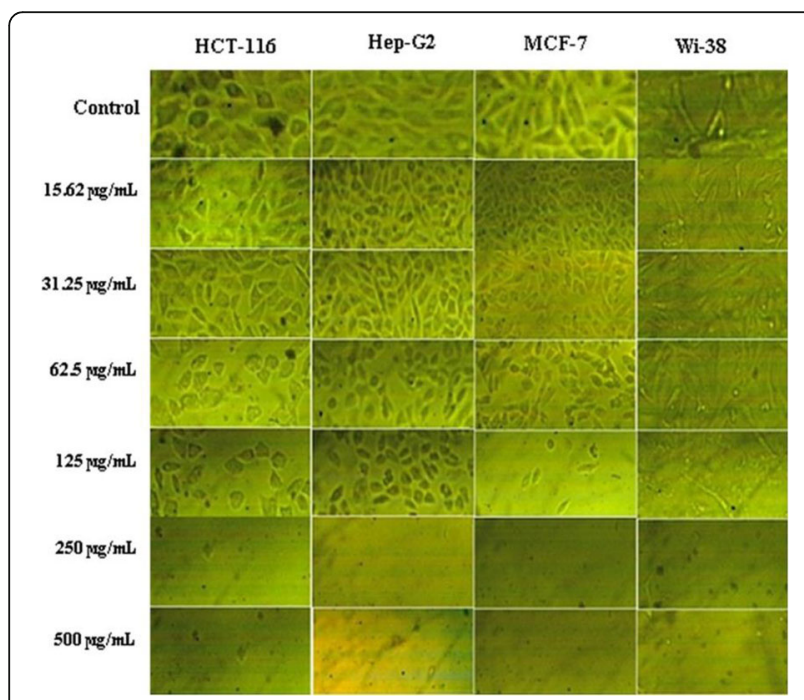

Fig. 4 Cytotoxic effect and variation in morphological characteristics of human colon carcinoma cell line (HCT-116), hepatocellular carcinoma cell line (Hep-G2), breast cancer cell line (MCF-7), and normal human lung fibroblast cells (Wi-38) treated with different concentrations $(15.62-500 \mu \mathrm{g} / \mathrm{mL})$ of Streptomyces sp. NMF6 extract compared with untreated cell lines (control) anticancer activity of either pure compounds or crude extracts derived from various marine Streptomyces species [7]. In the present study, the crude extract of Streptomyces sp. NMF6 associated with D. ardoukobae exhibited in vitro anticancer activity against three human cancer cell lines, viz., breast cancer cell line (MCF-7), hepatocellular carcinoma cell line (Hep-G2), and human colon carcinoma cell line (HCT-116), with the $\mathrm{IC}_{50}$ values being 55.65, 59.39, and $49.85 \mu \mathrm{g} / \mathrm{mL}$, respectively. The SI values of Streptomyces sp. NMF6 extract for all the tested cancer cell lines were $<2$, which indicates limited selectivity [59]. However, the purified compound responsible for the cytotoxic activity could be more selective toward malignant cells.

Virus diseases such as influenza, herpes simplex virus (HSV), human immunodeficiency virus, respiratory syncytial virus, enterovirus 71 (EV71), dengue virus, and Ebola virus, as well as the recently emerging coronavirus disease 2019 (COVID-19), have been a serious threat for human health and have caused millions of human deaths worldwide [60]. As viruses mutate their genome easily and spread rapidly due to urbanization, global travel, and migration, the treatment of viral infections (especially in the absence of vaccines and efficient antiviral drugs) represents a huge challenge [61]. Due to viral resistance and the toxic side effects associated with the existing antiviral drugs, it has become necessary to explore novel antiviral compounds with different mechanisms of action to manage viral infections [62]. Marine microorganisms are well-known producers of antiviral

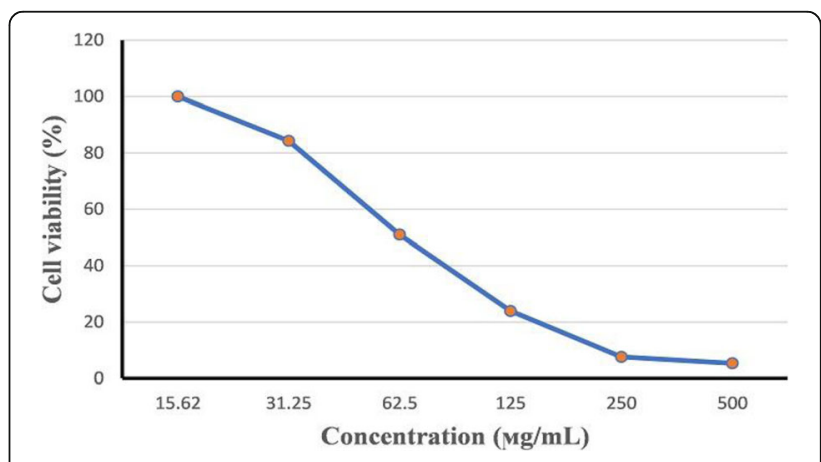

Fig. 5 Cytotoxicity of NMF6 extract on Vero cells 


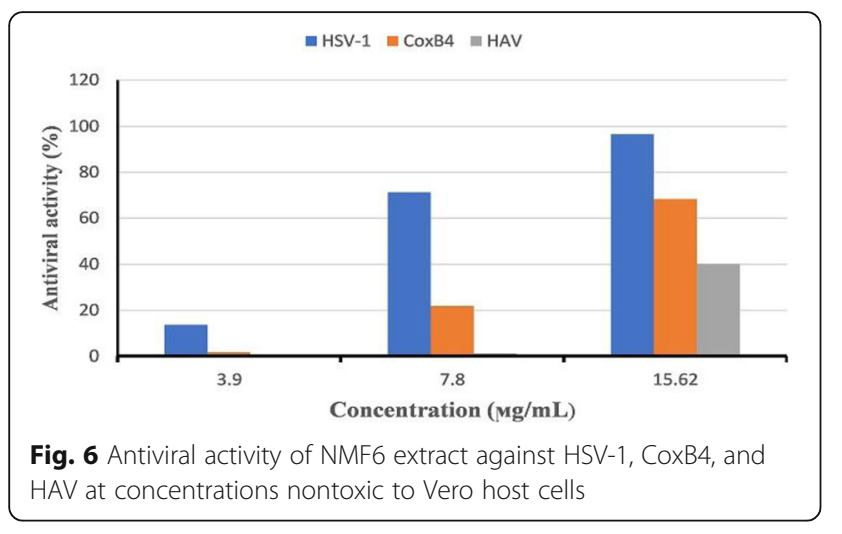

agents. A total of 89 antiviral compounds representing eight structural classes have been isolated from marine microbes between 2015 and 2019 [63]. Several studies have reported that marine streptomycetes are excellent producers of antiviral compounds [64-69]. In the present study, the antiviral activity of EtOAc derived from Streptomyces sp. NMF6 was evaluated using the MTT antiviral protocol, and the results showed that the extract exhibited promising antiviral activity against HSV-1, CoxB4, and HAV at nontoxic concentrations, with high SI values of 13.25, 9.42, and 8.25, respectively, which indicate differential selectivity [70]. As viruses are abundant in the marine environment and interact with microbial communities as well as marine organisms [71], the strain NMF6 may produce antiviral secondary metabolites as defensive compounds in response to viral attack of the microbial community or the host sponge.

GC-MS analysis has played a role in the bioprospecting of natural products from streptomycetes [72-74]. More than $50 \%$ of the EtOAc of strain NMF6 contained phthalate esters, whereas polyketide compounds accounted for approximately $25 \%$ of whole extract. Phthalate ester compounds were earlier known as pollutants, but in the past few years, it has been found that microorganisms such as bacteria and fungi are able to synthesize these compounds [75]. Bis-(2-ethylhexyl) phthalate is the major compound of NMF6 strain extract; this compound has been frequently isolated from several microbial sources such as Streptomyces [76], Nocardia [77], and Aspergillus [78]. Polyketide secondary metabolites are found in bacteria, fungi, and plants and represent one of the largest groups of natural products [79]. They are structurally classified into four groups, viz., aromatics, macrolides, polyethers, and polyenes. Most of these compounds are valuable antibiotics or exhibit other pharmacological activities [80].

\section{Conclusions}

The study has demonstrated that the marine sponge $D$. ardoukobae hosts bioactive actinomycetes, and the

Table 6 Chemical compounds detected in the EtOAc of strain NMF6 by GC-MS analysis

\begin{tabular}{|c|c|c|c|c|}
\hline RT & Compound name & M.W & M.F & Area $\%$ \\
\hline 14.54 & Hydroquinone (1) & 110 & $\mathrm{C}_{6} \mathrm{H}_{6} \mathrm{O}_{2}$ & 2.61 \\
\hline 14.91 & 1-Tetradecanol (2) & 214 & $\mathrm{C}_{14} \mathrm{H}_{30} \mathrm{O}$ & 0.42 \\
\hline 15.12 & 1-Hexadecanol (3) & 242 & $\mathrm{C}_{16} \mathrm{H}_{34} \mathrm{O}$ & 1.50 \\
\hline 16.30 & 2-Allyl-5-t-butylhydroquinone (4) & 206 & $\mathrm{C}_{13} \mathrm{H}_{18} \mathrm{O}_{2}$ & 0.64 \\
\hline 16.63 & Eicosane (5) & 282 & $\mathrm{C}_{20} \mathrm{H}_{42}$ & 0.79 \\
\hline 18.09 & Docosane (6) & 310 & $\mathrm{C}_{22} \mathrm{H}_{46}$ & 0.81 \\
\hline 18.29 & 1-Nonadecene (7) & 266 & $\mathrm{C}_{19} \mathrm{H}_{38}$ & 4.74 \\
\hline 18.91 & 1,2-Propanediol, 3-(octadecyloxy)-, diacetate (8) & 428 & $\mathrm{C}_{25} \mathrm{H}_{48} \mathrm{O}_{5}$ & 0.56 \\
\hline 20.86 & Methyl Nonadecanoate (9) & 312 & $\mathrm{C}_{20} \mathrm{H}_{40} \mathrm{O}_{2}$ & 0.66 \\
\hline 21.18 & 1-Docosene (10) & 308 & $\mathrm{C}_{22} \mathrm{H}_{44}$ & 3.95 \\
\hline 21.49 & Methyl 14-methylpentadecanoate (11) & 270 & $\mathrm{C}_{17} \mathrm{H}_{34} \mathrm{O}_{2}$ & 1.50 \\
\hline 22.95 & Diisobutyl phthalate (12) & 278 & $\mathrm{C}_{16} \mathrm{H}_{22} \mathrm{O}_{4}$ & 1.43 \\
\hline 23.55 & 7,9-Di-tert-butyl-1-oxaspiro (4,5) deca-6,9-Diene-2,8-dione (13) & 276 & $\mathrm{C}_{17} \mathrm{H}_{24} \mathrm{O}_{3}$ & 1.05 \\
\hline 23.71 & Erucic acid (14) & 338 & $\mathrm{C}_{22} \mathrm{H}_{42} \mathrm{O}_{2}$ & 0.58 \\
\hline 23.83 & 1-Docosanol (15) & 326 & $\mathrm{C}_{22} \mathrm{H}_{46} \mathrm{O}$ & 2.26 \\
\hline 24.52 & Phthalic acid, butyl 8-methylnonyl ester (16) & 362 & $\mathrm{C}_{22} \mathrm{H}_{34} \mathrm{O}_{4}$ & 3.74 \\
\hline 26.07 & Dotriacontane (17) & 450 & $\mathrm{C}_{32} \mathrm{H}_{66}$ & 1.68 \\
\hline 27.91 & Dioctyl hexanedioate (18) & 370 & $\mathrm{C}_{22} \mathrm{H}_{42} \mathrm{O}_{4}$ & 1.61 \\
\hline 28.53 & Oleic acid 3-(octadecyloxy) propyl ester (19) & 592 & $\mathrm{C}_{39} \mathrm{H}_{76} \mathrm{O}_{3}$ & 0.58 \\
\hline 30.74 & Bis(2-ethylhexyl) phthalate (20) & 390 & $\mathrm{C}_{24} \mathrm{H}_{38} \mathrm{O}_{4}$ & 48.90 \\
\hline
\end{tabular}




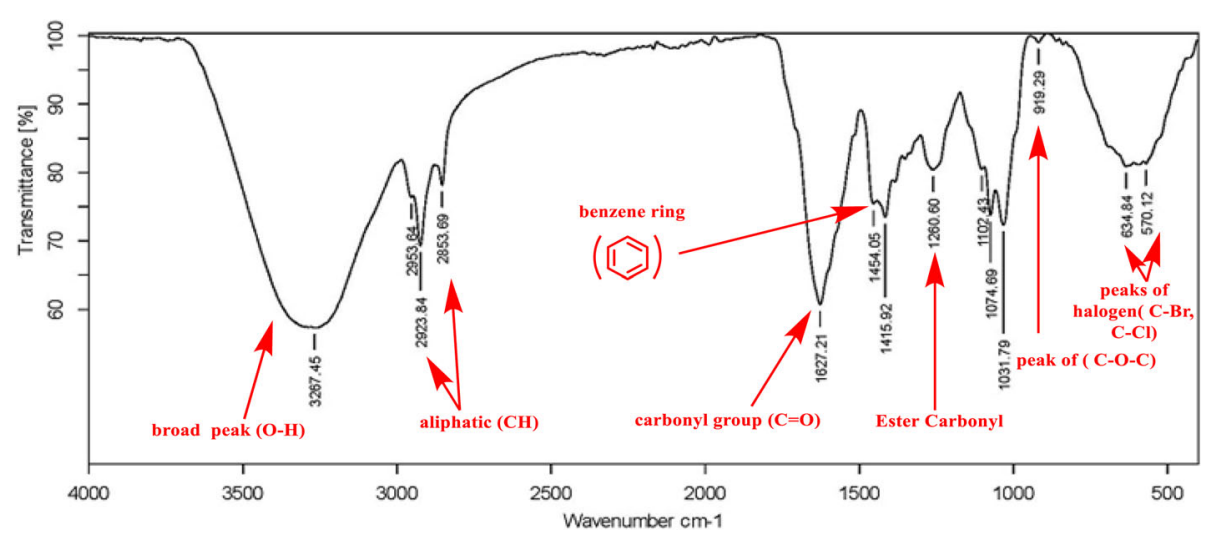

Fig. 7 IR spectrum of the EtOAc of NMF6 strain

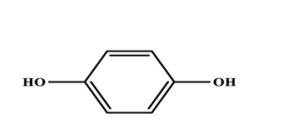

(1)<smiles>C=CCc1cc(C)c(C(C)(C)C)cc1C</smiles>

(4)

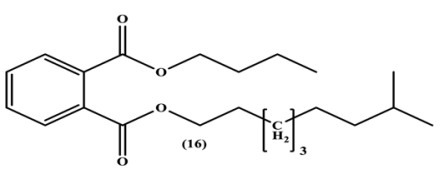

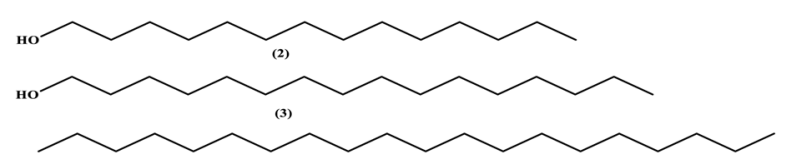

(5)

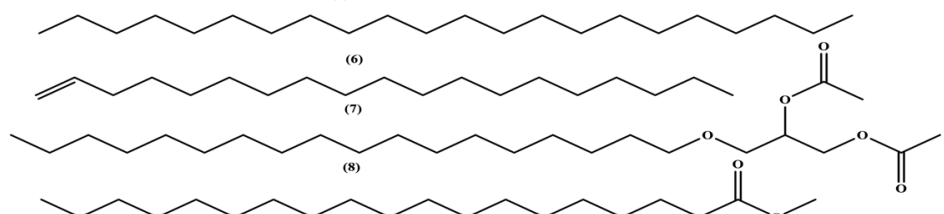<smiles>CC(C)COC(=O)c1ccccc1C(=O)OCC(C)C</smiles><smiles>C=CCC</smiles><smiles>c1ccccc1</smiles><smiles>C=C1CCC2(C=C(C(C)(C)C)C(C(C)(C)C)C=C2C)C1</smiles>

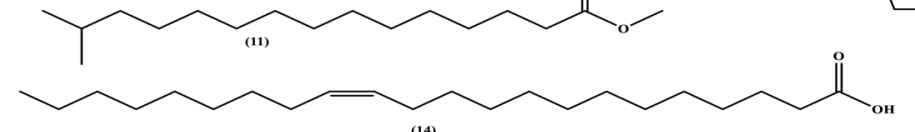<smiles>CCCCCCCCCCCCCCCCCCCCCC</smiles><smiles>CCCCCCCCCCC=CCCCCCCCC[14CH2]CCCC</smiles>

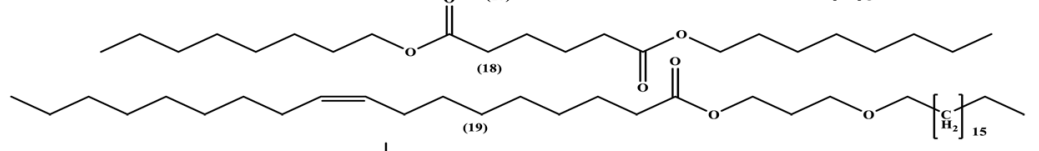<smiles>C=C(CCC(CC)CCCC)c1ccccc1C(=C)CCC(CC)CCCC</smiles>

Fig. 8 Chemical structures of the compounds identified in NMF6 extract 
potential of Streptomyces sp. NMF6 strain as a source of industrial and pharmaceutical products was evaluated. The strain secretes extracellular hydrolytic enzymes of industrial interest and produces secondary metabolites possessing various biological activities. The EtOAc of strain NMF6 exhibited antimicrobial activity against gram-negative and gram-positive bacteria and unicellular fungi; anticancer activity against breast cancer cell line (MCF-7), hepatocellular carcinoma cell line (Hep-G2), and human colon carcinoma cell line (HCT-116); and antiviral activity against HSV-1, HAV, and CoxB4. Furthermore, the extract demonstrated promising antioxidant activities as evaluated by different methods, including DPPH, phosphomolybdenum, and ferricreducing power assays. Therefore, the strain NMF6 attracts interest for further studies concerning the manipulation of culture conditions to obtain maximum efficiency in producing enzymes and bioactive secondary metabolites. Further studies regarding separation, purification, and structure elucidation of the bioactive compounds are required.

\section{Abbreviations}

EtOAc: Ethyl acetate; TBHQ: Tert-butylated hydroquinone; BHA: Butylated hydro anisole; BHT: Butylated hydro toluene; SCNA: Starch casein nitrate agar; DMSO: Dimethyl sulfoxide; DPPH: 1-Diphenyl-2-picrylhydrazyl; AAEA

C: Ascorbic acid equivalent antioxidant capacity; RPMI: Roswell Park Memorial Institute 1640 medium; MTT: 3-(4,5-Dimethylthiazol-2-yl)-2,5-

diphenyltetrazolium bromide; $I C_{50}$ : Half maximal inhibitory concentration;

$\mathrm{CC}_{50}$ : The concentration that caused 50\% toxicity; S: Staphylococcus;

C: Candida; V: Vibrio; E: Enterococcus

\section{Acknowledgements}

Not applicable

\section{Authors' contributions}

NMF is the main author carried out the isolation and characterization of NMF6 stain, fermentation and extraction of secondary metabolite(s), bioactivity evaluation, and wrote the manuscript. AMA carried out the GS-MS of the structural analysis and involved in the writing process. The authors read and approved the final manuscript.

\section{Funding}

None

\section{Availability of data and materials}

All data generated or analyzed during this study are included in this published article.

\section{Declarations}

\section{Ethics approval and consent to participate}

This article does not contain any studies involving animals or human participants performed by any of the authors.

\section{Consent for publication}

Not applicable

\section{Competing interests}

The authors declare that they have no competing interests.

\section{Author details}

${ }^{1}$ Marine Microbiology Laboratory, National Institute of Oceanography and Fisheries, Cairo, Egypt. ${ }^{2}$ Marine Biotechnology and Natural Products Laboratory, National Institute of Oceanography and Fisheries, Cairo, Egypt.
Received: 6 April 2021 Accepted: 30 June 2021

Published online: 15 July 2021

\section{References}

1. Serwecinska $L$ (2020) Antimicrobials and antibiotic-resistant bacteria: a risk to the environment and to public health. Water 12(12):3313. https://doi. org/10.3390/w12123313

2. Sanjuan R, Domingo-Calap P (2016) Mechanisms of viral mutation. Cell Mol Life Sci 73(23):4433-4448. https://doi.org/10.1007/s00018-016-2299-6

3. Bray F, Ferlay J, Soerjomataram I, Siegel RL, Torre LA, Jemal A (2018) Global cancer statistics 2018: GLOBOCAN estimates of incidence and mortality worldwide for 36 cancers in 185 countries. CA A Cancer JClin 68(6):394-424. https://doi.org/10.3322/caac.21492

4. Davies-Bolorunduro OF, Adeleye IA, Akinleye MO, Wang PG (2019) Anticancer potential of metabolic compounds from marine actinomycetes isolated from Lagos Lagoon sediment. J Pharm Anal 9(3):201-208. https:// doi.org/10.1016/j.jpha.2019.03.004

5. Nieva-Echevarría B, Manzanos MJ, Goicoechea E, Guillén MD (2015) 2,6-ditert-Butyl-hydroxytoluene and its metabolites in foods. Compr Rev Food Sci Food Saf 14(1):67-80. https://doi.org/10.1111/1541-4337.12121

6. Chandra P, Sharma RK, Arora DS (2020) Antioxidant compounds from microbial sources: a review. Food Res Int 129:108849. https://doi.org/10.101 6/j.foodres.2019.108849

7. Law JWF, Law LNS, Letchumanan V, Tan LTH, Wong SH, Chan KG, Ab Mutalib NS, Lee LH (2020) Anticancer drug discovery from microbial sources: the unique mangrove streptomycetes. Molecules 25(22):5365. https://doi.org/10.3390/molecules25225365

8. Sorokina M, Steinbeck C (2020) Review on natural products databases: where to find data in 2020. Aust J Chem 12(1):20. https://doi.org/10.1186/ s13321-020-00424-9

9. Molinski TF, Dalisay DS, Lievens SL, Saludes JP (2009) Drug development from marine natural products. Nat. Rev. Drug Des Discov 8(1):69-85. https:// doi.org/10.1038/nrd2487

10. Adnan M, Alshammari E, Patel M, Amir AS, Khan S, Hadi S (2018) Significance and potential of marine microbial natural bioactive compounds against biofilms/biofouling: necessity for green chemistry. PeerJ 6:e5049. https://doi.org/10.7717/peerj.5049

11. Stien D (2020) Marine microbial diversity as a source of bioactive natural products. Mar Drugs 18(4):215. https://doi.org/10.3390/md18040215

12. Dharmaraj S (2010) Marine Streptomyces as a novel source of bioactive substances. World J Microbiol Biotechnol 26(12):2123-2139. https://doi.org/1 0.1007/s11274-010-0415-6

13. Abdelmohsen UR, Bayera K, Hentschela U (2014) Diversity, abundance and natural products of marine sponge-associated actinomycetes. Nat Prod Rep 31(3):381-399. https://doi.org/10.1039/C3NP70111E

14. Horn H, Hentschel U, Abdelmohsen UR (2015) Mining genomes of three marine sponge-associated actinobacterial isolates for secondary metabolism. Genome Announc 3:e01106-e01115

15. Imamura N, Nishijima M, Adachi K, Sano H (1993) Novel antimycin antibiotics, urauchimycins $\mathrm{A}$ and $\mathrm{B}$, produced by marine actinomycete. J Antibiot 46(2):241-246. https://doi.org/10.7164/antibiotics.46.241

16. Yao CBF, Schiebel M, Helmke $E$, Anke H, Laatsch $H$ (2006) Prefluostatin and new urauchimycin derivatives produced by streptomycete isolates. Z Naturforsch B 61(3):320-325. https://doi.org/10.1515/znb-2006-0312

17. Khan ST, Komaki H, Motohashi K, Kozone I, Mukai A, Takagi M, Shin-ya K (2011) Streptomyces associated with a marine sponge Haliclona sp.; biosynthetic genes for secondary metabolites and products. Environ. Microbiol 13(2):391-403

18. Li K, Li QL, Ji NY, Liu B, Zhang W, Cao XP (2011) Deoxyuridines from the marine sponge associated actinomycete Streptomyces microflavus. Mar Drugs 9(5):690-695. https://doi.org/10.3390/md9050690

19. Abdelmohsen UR, Zhang G, Philippe A, Schmitz W, Pimentel-Elardo SM, Hertlein-Amslinger B, Hentschel U, Bringmann G (2012) Cyclodysidins A-D, cyclic lipopeptides from the marine sponge-derived Streptomyces strain RV15. Tetrahedron Lett 53(1):23-29. https://doi.org/10.1016/j.tetlet.2011.10. 051

20. Balasubramanian S, Othman EM, Kampik D, Stopper H, Hentschel U, Ziebuhr W, Oelschlaeger TA, Abdelmohsen UR (2017) Marine sponge-derived Streptomyces sp. Sbt343 extract inhibits staphylococcal biofilm formation. Front Microbiol 8:236 
21. Huang X, Zhou S, Huang D, Chen J, Zhu W (2015) Streptomyces spongiicola sp. nov., an actinomycete derived from marine sponge. Int I Syst Evol Microbiol:738-743

22. Williams S, Davies F (1965) Use of antibiotics for selective isolation and enumeration of actinomycetes in soil. Microbiology 38:251-261. https://doi. org/10.1099/00221287-38-2-251

23. Shirling EB, Gottlieb D (1966) Methods for characterization of Streptomyces species. Int J Syst Bacteriol 16(3):313-340. https://doi.org/10.1099/002 07713-16-3-313

24. Kumar V, Bharti A, Gusain O, Bisht GS (2011) Scanning electron microscopy of Streptomyces without use of any chemical fixatives. Scanning 33:1-4

25. Williams S, Goodfellow M, Alderson G, Wellington E, Sneath P, Sackin M (1983) Numerical classification of Streptomyces and related genera. J Gen Microbiol 129(6):1743-1813. https://doi.org/10.1099/00221287-129-6-1743

26. Kumar V, Naik B, Gusain O, Bisht GS (2014) An actinomycete isolate from solitary wasp mud nest having strong antibacterial activity and kills the Candida cells due to the shrinkage and the cytosolic loss. Front Microbiol 5: 446

27. Sambrook J, Russell DW (2001) Molecular cloning-a laboratory manual, 3rd edn. Cold Spring Harbor Laboratory, New York

28. Hall BG (2013) Building phylogenetic trees from molecular data with MEGA. Mol Biol Evol 30(5):1229-1235. https://doi.org/10.1093/molbev/mst012

29. Romankova A, Zurabova E, Fursenko M, Sukharevich V, Pronina M (1971) Selection of strains of some antibiotic producing actinomycetes during repeated passages in submerged cultures. Antibiotiki 16:579-583

30. Selvameenal L, Radhakrishnan M, Balagurunathan R (2009) Antibiotic pigment from desert soil actinomycetes; biological activity, purification and chemical screening. Indian J Pharm Sci 71:499-504. https://doi.org/10.4103/ 0250-474X.58174

31. Balouiri M, Sadiki M, Ibnsouda SK (2016) Methods for in vitro evaluating antimicrobial activity: a review. J Pharm Anal 6(2):71-79. https://doi.org/10.1 016/j.jpha.2015.11.005

32. Kasangana PB, Haddad PS, Stevanovic T (2015) Study of polyphenol content and antioxidant capacity of Myrianthus arboreus (cecropiaceae) root bark extracts. Antioxidants 4(2):410-426. https://doi.org/10.3390/antiox4020410

33. Aliyu AB, Ibrahim MA, Musa AM, Musa AO, Kiplimo JJ, Oyewale AO (2013) Free radical scavenging and total antioxidant capacity of root extracts of Anchomanes difformis engl. (Araceae). Acta Pol Pharm 70(1):115-121

34. Slater TF, Sawyer B, Strauli U (1963) Studies on succinate-tetrazolium reductase systems III. Points of coupling of four different tetrazolium salts. Biochim Biophys Acta 77:383-393

35. Alley MC, Scudiero DA, Monks A, Hursey ML, Czerwinski MJ, Fine DL, Abbott BJ, Mayo JG, Shoemaker RH, Boyd MR (1988) Feasibility of drug screening with panels of tumor human cell lines using a microculture tetrazolium assay. Cancer Res 48:589-560

36. van de Loosdrecht AA, Beelen RH, Ossenkoppele GJ, Broekhoven MG, Langenhuijsen MM (1994) A tetrazolium-based colorimetric MTT assay to quantitate human monocyte mediated cytotoxicity against leukemic cells from cell lines and patients with acute myeloid leukemia. J Immunol Methods 174(1-2):311-320. https://doi.org/10.1016/0022-1 759(94)90034-5

37. Todorov D, Shishkova K, Dragolova D, Hinkov A, Kapchina-Toteva V, Shishkov S (2015) Antiviral activity of medicinal plant Nepeta nuda. Biotechnol Biotechnol Equip 29(S1):S39-S43. https://doi.org/10.1080/13102 818.2015.1047215

38. Andrighetti-Fröhner R, AntonioV C-PB, Barardi M, Simões O (2003) Cytotoxicity and potential antiviral evaluation of violacein produced by Chromobacterium violaceum. Mem Inst Oswaldo Cruz 98(6):843-848. https:// doi.org/10.1590/S0074-02762003000600023

39. Jerković I, Tuberoso CIG, Baranović G, Marijanović Z, Kranjac M, Svečnjak I, Kuśf PM (2015) Characterization of summer savory (Satureja hortensis l.) Honey by physico-chemical parameters and chromatographic/spectroscopic techniques (GCFID/MS, HPLC-DAD, UVNIS and FTIR-ATR). J Croatica Chemica Acta 88(1):15-22. https://doi.org/10.5562/cca2514

40. Hentschel U, Piel J, Degnan SM, Taylor MW (2012) Genomic insights into the marine sponge microbiome. Nat Rev Microbiol 10:641-654

41. Goodfellow M (2012) Phylum XXVI. Actinobacteria phyl. nov. In: Bergey's manual $^{\otimes}$ of systematic bacteriology. Springer, New York, pp 33-2028. https://doi.org/10.1007/978-0-387-68233-4_3

42. Davelos AL, Xiao K, Flor JM, Kinkel LL (2004) Genetic and phenotypic traits of streptomycetes used to characterize antibiotic activities of field- collected microbes. Can J Microbiol 50(2):79-89. https://doi.org/10.1139/ w03-107

43. Lee LH, Zainal N, Azman AS, Eng SK, Ab Mutalib NS, Yin WF, Chan KG (2014) Streptomyces pluripotens sp. nov., a bacteriocin-producing streptomycete that inhibits meticillin-resistant Staphylococcus aureus. Int I Syst Evo Microbiol 64(Pt 9):3297-3306. https://doi.org/10.1099/ijs.0.065045-0

44. Barnes DK (1999) High diversity of tropical intertidal zone sponges in temperature, salinity and current extremes. Afr J Ecol 37(4):424-434. https:// doi.org/10.1046/j.1365-2028.1999.00197.x

45. Gupta N, Mishra S, Basak U (2009) Diversity of Streptomyces in mangrove ecosystem of Bhitarkanika. Iran J Microbiol 1(3):37-42

46. de Lima Procópioa RE, da Silvaa IR, Martinsa MK, de Azevedoa JL, de Araújob JM (2012) Antibiotics produced by Streptomyces. Braz J Infect Dis 16(5):466-471

47. Santos-Sánchez NF, Salas-Coronado R, Villanueva-Cañongo C, HernándezCarlos B (2019) Antioxidant compounds and their antioxidant mechanism. In: Antioxidants. IntechOpen. https://doi.org/10.5772/intechopen.85270

48. Sindhi V, Gupta V, Sharma K, Bhatnagar S, Kumari R, Dhaka N (2013) Potential applications of antioxidants: a review. J Pharm Res 7(8):28-835

49. Rao KVR, Rao TR (2013) Molecular characterization and its antioxidant activity of a newly isolated Streptomyces coelicoflavus BC 01 from mangrove soil. J Young Pharm 5(4):121-126. https://doi.org/10.1016/j.jyp.2013.10.002

50. Kemung HML, Tan TH, Chan KG et al (2019). Investigating the antioxidant potential of Streptomyces sp. MUSC 11 from mangrove soil in Malaysia PDDBS (2):1 doi: https://doi.org/10.36877/pddbs.a0000033.

51. Tan LTHT, Chan KG, Pusparajah P, Yin WF, Khan TM, Lee LH, Goh BH (2019) Mangrove derived Streptomyces sp. MUM265 as a potential source of antioxidant and anticolon-cancer agents. BMC Microbiol 19:38. https://doi. org/10.1186/s12866-019-1409-7

52. Tan LTH, Chan KG, Khan TM et al (2017) Streptomyces sp. MUM212 as a source of antioxidants with radical scavenging and metal chelating properties. Front Pharmacol 8(1):276. https://doi.org/10.3389/fphar.2017.002 76

53. Kemung HM, Tan LTH, Chan KG, Ser HL, Law JWF, Lee LH, Goh BH (2020) Antioxidant activities of Streptomyces sp. strain MUSC 14 from mangrove forest soil in Malaysia. Bio Med Res Int. https://doi.org/10.1186/s12866-01 9-1409-7

54. Hartwig VG, Brumovsky LA, Fretes RM, Boado LS (2012) A novel procedure to measure the antioxidant capacity of yerba maté extracts. Food Sci. Techno 32(1):126-133. https://doi.org/10.1590/S0101-20612012 005000022

55. David B, Wolfender JL, Dias DA (2015) The pharmaceutical industry and natural products: historical status and new trends. Phytochem Rev 14(2): 299-315. https://doi.org/10.1007/s11101-014-9367-z

56. Khalifa SAM, Elias N, Farag MA, Chen L, Saeed A, Hegazy MEF, Moustafa MS, Abd el-Wahed A, al-Mousawi SM, Musharraf SG, Chang FR, Iwasaki A, Suenaga K, Alajlani M, Göransson U, el-Seedi HR (2019) Marine natural products: a source of novel anticancer drugs. Mar Drugs 17(9):491. https:// doi.org/10.3390/md1709049

57. Demain AL, Vaishnav P (2011) Natural products for cancer chemotherapy. Microb Biotechnol 4(6):687-699. https://doi.org/10.1111/j.1751-7915.2010. 00221.x

58. Bhattacharya B, Mukherjee S (2015) Cancer therapy using antibiotics. J Cancer Ther 6(10):849-858. https://doi.org/10.4236/jct.2015.610093

59. López-Lázaro MA (2015) Simple and reliable approach for assessing anticancer activity in vitro. Curr Med Chem 22(11):1324-1334. https://doi. org/10.2174/0929867322666150209150639

60. Yi M, Lin S, Zhang B, Jin H, Ding L (2020) Antiviral potential of natural products from marine microbes. Eur J Med Chem 207:112790. https://doi. org/10.1016/j.ejmech.2020.112790

61. Neiderud CJ (2015) How urbanization affects the epidemiology of emerging infectious diseases. Infect Ecol Epidemiol 5:27060

62. Riccio G, Ruocco N, Mutalipassi M, Costantini M, Zupo V, Coppola D, de Pascale D, Lauritano C (2020) Ten-year research update review: antiviral activities from marine organisms. Biomolecules 10(7):1007. https://doi.org/1 0.3390/biom10071007

63. Teng YF, Xu L, Wei MY, Wang CY, Gu YC, Shao CL (2020) Recent progresses in marine microbial-derived antiviral natural products. Arch Pharm Res 43(12):1215-1229. https://doi.org/10.1007/s12272-020-01286-3 
64. Liu H, Chen Z, Zhu G, Wang L, Du Y, Wang Y, Zhu W (2017) Phenolic polyketides from the marine alga-derived Streptomyces sp. OUCMDZ-3434. Tetrahedron 73(36):5451-5455. https://doi.org/10.1016/j.tet.2017.07.052

65. Manimaran M, Rajkumar T, Vimal S, Taju G, Majeed SA, Hameed AS, Kannabiran K (2018) Antiviral activity of 9 (10H)-Acridanone extracted from marine Streptomyces fradiae strain VITMK2 in Litopenaeus vannamei infected with white spot syndrome virus. Aquaculture 488:66-73. https://doi.org/10.1 016/j.aquaculture.2018.01.032

66. Huang $H$, Song $Y$, Li X, Wang X, Ling C, Qin X, Zhou Z, Li Q, Wei X, Ju J (2018) Abyssomicin monomers and dimers from the marine-derived Streptomyces koyangensis SCSIO 5802. J Nat Prod 81(8):1892-1898. https:// doi.org/10.1021/acs.jnatprod.8b00448

67. Hou L, Wang S, Huang H, Li H, Wang W, Li W (2018) Generation of methylated violapyrones with improved anti-influenza A virus activity by heterologous expression of a type III PKS gene in a marine Streptomyces strain. Bioorg Med Chem Lett 28(17):2865-2868. https://doi.org/10.1016/j. bmcl.2018.07.029

68. Che Q, Qiao L, Han X, Liu Y, Wang W, Gu Q, Zhu T, Li D (2018) Anthranosides $\mathrm{A}-\mathrm{C}$, anthranilate derivatives from a sponge derived Streptomyces sp. CMN-62. Org Lett 20(17):5466-5469. https://doi.org/10.1 021/acs.orglett.8b02382

69. Huang H, Song Y, Zang R, Wang X, Ju J (2019) Octyl substituted butenolides from marine-derived Streptomyces koyangensis. Nat Prod Res 5:1-6

70. Koch A, Tamez P, Pezzuto J, Soejarto D (2005) Evaluation of plants used for antimalarial treatment by the Massai of Kenya. J Ethnopharmacol 101(1-3): 95-99. https://doi.org/10.1016/j.jep.2005.03.011

71. Suttle CA (2005) Viruses in the sea. Nature 437(7057):356-361. https://doi. org/10.1038/nature04160

72. Schöller CE, Gürtler H, Pedersen R, Molin S, Wilkins K (2002) Volatile metabolites from actinomycetes. J Agric Food Chem 50(9):2615-2621. https://doi.org/10.1021/jf0116754

73. Ser HL, Ab Mutalib NS, Yin WF, Chan KG, Goh B-H, Lee LH (2015) Evaluation of antioxidative and cytotoxic activities of Streptomyces pluripotens MUSC 137 isolated from mangrove soil in Malaysia. Front Microbiol 6:1398

74. Selvakumar JN, Chandrasekaran SD, Vaithilingam M (2015) Bio prospecting of marine-derived Streptomyces spectabilis VITJS10 and exploring its cytotoxicity against human liver cancer cell lines. Pharmacogn Mag 11(44): 469

75. El-Sayed MH (2012) Di-(2-ethylhexyl) Phthalate, a major bioactive metabolite with antimicrobial and cytotoxic activity isolated from the culture filtrate of newly isolated soil Streptomyces (Streptomyces mirabilis Strain NSQu-25). World Appl Sci J 20(9):1202-1212

76. Al-Bari MA, Bhuiyan MSA, Flores ME, Petrosyan P, Varela MG, Islam MAU (2005) Streptomyces bangladeshensis sp. nov., isolated from soil, which produces bis-(2-ethylhexyl)phthalate. Int J Syst Evol Microbiol 55(5):19731977. https://doi.org/10.1099/ijs.0.63516-0

77. Kavitha A, Prabhakar P, Vijayalakshmi M, Venkateswarlu Y (2009) Production of bioactive metabolites by Nocardia levis MK-VL_113. Lett Appl Microbiol 49(4):484-490. https://doi.org/10.1111/j.1472-765X.2009.02697.x

78. Lotfy MM, Hassan HM, Hetta MH, El-Gendy AO, Mohammed R (2018) Di-(2ethylhexyl) Phthalate, a major bioactive metabolite with antimicrobial and cytotoxic activity isolated from River Nile derived fungus Aspergillus awamori. BJBAS 7:263-269

79. Yuzawa S, Kuzuyama T (2020) Comprehensive natural products III. Chem Biol 1:123-138

80. Leeper FJ, Vederas JC (2003) Biosynthesis: aromatic polyketides, isoprenoids, alkaloids. springer

\section{Publisher's Note}

Springer Nature remains neutral with regard to jurisdictional claims in published maps and institutional affiliations.

\section{Submit your manuscript to a SpringerOpen ${ }^{\circ}$ journal and benefit from:}

- Convenient online submission

- Rigorous peer review

- Open access: articles freely available online

- High visibility within the field

- Retaining the copyright to your article

Submit your next manuscript at $\boldsymbol{\nabla}$ springeropen.com 